\title{
PEMASYARAKATAN DAUR ULANG AIR LIMBAH UNTUK MENGANTISIPASI KELANGKAAN AIR AKIBAT PERUBAHAN IKLIM GLOBAL
}

\author{
Dissemination Of Waste Water Recycling For Water Scarcity Anticipation Due To Global Climate Change \\ Oleh: \\ Rudi Nugroho \\ Pusat Teknologi Lingkungan, Badan Pengkajian dan Penerapan Teknologi.
}

\begin{abstract}
Abstrak
Perubahan iklim global membawa dampak kepada semua sektor di muka bumi tanpa kecuali sektor sumber daya air. Sebagai contoh nyata yakni banyak terjadinya banjir dan kekeringan di Indonesi, sehingga perlu dilakukan langkah-langkah antisipasinya. Di dalam dokumen Technology Needs Assessment Republik Indonesia, langkah-langkah adaptasi yang menjadi prioritas untuk menghadapi perubahan iklim sektor sumber daya air ada, dimana salah satunya adalah daur ulang air limbah domestik. Daur ulang air limbah dapat dilakukan dengan melalui dua tahapan proses yakni pengolahan air limbah itu sendiri sampai batas baku mutu yang diperkenankan untuk dibuang ke lingkungan, kemudian dilanjutkan dengan pengolahan air limbah tersebut sampai hasilnya dapat dipergunakan untuk suatu keperluan tertentu. Teknologi yang dapat digunakan ada berbagai macam tergantung dari kualitas air olahan yang diinginkan. Pemanfaatan air daur ulang di masyarakat sampai saat ini masih sangat sedikit karena terkendala faktor teknis maupun non teknis (sosial, ekonomi, peraturan dan lain lain) yang perlu diantisipasi bersama. Kendala teknis adalah mencakup teknologi yang relatif lebih mahal untuk mengolah air limbah menjadi produk yang dapat dimanfaatkan. Sedangkan kendala non teknis yakni masih banyaknya masyarakat yang masih enggan menggunakan air daur ulang karena faktor psikologis. Oleh karena itu pemasyarakatan daur ulang air limbah diharapkan dapat membantu mengeliminasi kendala-kendala yang ada yang pada akhirnya akan dapat mengurangi resiko krisis air di masa mendatang.
\end{abstract}

Kata kunci: Daur ulang air, limbah domestik, perubahan iklim global.

\begin{abstract}
Climate change has impact on many sectors in the earth such as on the water resources sector. For example, the occurrence of floods and droughts in Indonesia that needs to be anticipated. In the Technology Needs Assessment document of the Republic of Indonesia, there are three priorities technology of the water sector to anticipate the climate change. One of the technologies is recycling domestic wastewater. The recycling of waste water can be done through two consecutive stages. First, wastewater treatment processes itself to produce the quality standard limits allowed to be discharged into the environment. Second is processing the treated wastewater till the product water can be used for particular purpose. There are many technologies can be used for water recycling process. Selection of technology depends on the type of waste water and product water quality targets. The utilization of recycled water in the community is still very little due to the barriers of technical and non-technical factors (social, economic, regulatory and others) which need to be anticipated along. Technical barrier include technology that is relatively more expensive to treat wastewater into products that can be utilized. While the non-technical barrier is many people are still reluctant to use the recycled water due to psychological factors. Therefore sosialization of waste water recycling to be expected can eliminate such barriers.
\end{abstract}

Keywords: Water recycling, domestic waste, global climate change.

\section{PENDAHULUAN}

Air adalah kebutuhan penting untuk kegiatan manusia. Masalah yang dihadapi dalam hal sumber daya air di Indonesia adalah kelangkaan, baik kuantitas dan kualitas. Untuk beberapa lokasi, jumlah ketersediaan sumber daya air jauh lebih sedikit daripada yang dibutuhkan oleh kegiatan manusia. Salah satu penyebab masalah kerusakan sumber daya air di negara tropis Indonesia diyakini akibat dampak perubahan iklim. Oleh karena itu, kita perlu melakukan langkah-langkah adaptasi untuk mengelola sumber daya air yang terbatas. Adaptasi terhadap kerentanan sumber daya air harus 
dilakukan dalam jangka panjang serta tindakan jangka pendek.

Pernyataan dari UNDP yang menyatakan bahwa resiko terbesar akibat perubahan iklim akan dialami oleh kelompok penduduk miskin sebagai kelompok penduduk yang rentan. Kerentanan akan menjadi semakin tinggi ketika kelompok penduduk tersebut tinggal di wilayah perkotaan yang memiliki tingkat kepadatan penduduk yang tinggi. Salah satu issue yang dihadapi oleh penduduk perkotaan adalah masalah air bersih ${ }^{(12)}$. Kepadatan penduduk yang tinggi, pertambahan penduduk yang pesat, serta industrialisasi menyebabkan tekanan terhadap lahan, termasuk di dalamnya pada pemanfaatan air bersih menjadi melebihi kapasitas.

Krisis air bersih semakin menonjol ketika perubahan iklim terjadi. Perubahan siklus air telah menyebabkan dua keadaan yang ekstrim yaitu terjadinya peningkatan kondisi kekeringan yang akan mengurangi ketersediaan air tanah secara alami. Dampak perubahan iklim lainnya yaitu kenaikan muka air laut yang mengakibatkan peningkatan intrusi air laut yang akan memperburuk kualitas air bersih di kawasan daratan.

Perubahan kualitas dan kuantitas air bersih akibat perubahan iklim kenyataannya sudah terjadi secara perlahan. Jika selama ini sudah dilakukan beberapa penyesuaian terhadap perubahan tersebut, maka yang menjadi permasalahan berikutnya adalah apakah berbagai upaya yang dilakukan tersebut benar-benar dapat mengurangi resiko yang dihadapi dan menjamin keberlangsungan hidup mereka di masa mendatang atau memang hanya untuk tindakan sesaat saja. Penyesuaian terhadap kondisi lingkungan atau adaptasi yang dilakukan secara ideal diharapkan dapat menjamin keamanan hidup manusia.

Pemerintah Indonesia telah memasukkan beberapa pilihan adaptasi ke dalam rencana aksi nasional Mitigasi dan Adaptasi Perubahan Iklim Indonesia. Prioritas adaptasi sumber daya menurut Dokumen Negara "Indonesia's Technology Needs Assessment for Climate Change Adaptation", ada 3 (tiga) yakni pemanenan air hujan, daur ulang air limbah domestik dan pemodelan untuk mendapatkan proyeksi kebutuhan air mendatang (Anonim 1, 2011). Dalam makalah ini disampaikan pemasyarakatan daur ulang air limbah sebagai langkah adaptasi perubahan iklim global yang memungkinkan untuk dapat diterapkan di negara-negara berkembang seperti Indonesia dan Negara lainnya.

\section{AIR LIMBAH}

Air limbah dapat dikategorikan menjadi dua golongan besar yakni air limbah organik dan anorganik. Air limbah organik adalah air limbah yang mengandung polutan organik seperti karbohidrat, gula, protein dan lain sebagainya. Kategori limbah organik yang sering dijumpai adalah air limbah domestik, yakni air limbah yang berasal dari kegiatan manusia seperti toilet, kamar mandi, wastavel, kantin dan lain-lain. Untuk mengolah air limbah seperti ini, teknologi proses yang digunakan pada umumnya adalah proses pengolahan secara biologi, yakni pengolahan dengan memanfaatkan aktifitas mikroba. Sedangkan air limbah anorganik yakni air limbah yang mengandung polutan an organik seperti asam, basa, logam dan lain sebagainya, pengolahannya menggunakan proses fisika kimia seperti netralisasi, koagulasi flokulasi sedimentasi (Nugroho, 2011) ${ }^{(9)}$.

Di perkotaan, pencemaran oleh air limbah ke badan sungai berasal dari 3 sumber utama, yakni air limbah domestik permukiman, air limbah domestik gedung dan perkantoran serta air limbah industri. Di antara ketiga sumber tersebut, air limbah domestik permukiman menyumbang hampir $80 \%$ dari total air limbah yang dibuang ke lingkungan (JICA, 1990) ${ }^{(3)}$.

Pada prinsipnya air limbah domestik ini secara alami akan mengalami pemurnian sendiri (self purification) di alam. Apabila cemaran yang masuk ke alam badan air bebannya rendah, maka proses pemurnian sendiri akan cepat terjadi. Sebaliknya, apabila beban pencemaran yang dibuang ke alam kadarnya terlalu tinggi, proses pemurnian alami akan berjalan sangat lambat. Bahkan sampai beban pencemaran tertentu, alam sudah tidak dapat lagi melakukan pemurnian sendiri, sehingga kualitas air di badan-badan air sudah sangat buruk. Kasus yang terakhir inilah yang saat ini cenderung terjadi di DKI Jakarta ataupun kota kota besar lainnya di Indonesia. Karena yang diolah hanya yang dari toilet atau "black water" saja, sedangkan air limbah dari kamar mandi, dapur, wastavel yang dikenal dengan istilah "grey water" tidak dilakukan pengolahan melainkan langsung dibuang ke badan air. Karakteristik air limbah domestik dapat dilihat pada Tabel 1 (Lampiran).

Masyarakat di perkotaan rata-rata mengkonsumsi air bersih untuk keperluan sehari hari sekitar 200 - 250 liter per orang per hari. Dengan tingginya kebutuhan air per kapita, ditunjang dengan karakteristik kota dimana cenderung kepadatan penduduknya relatif tinggi dan meningkat dari tahun ke tahun, menjadikan tingginya pasokan air bersih di perkotaan. Air bersih yang telah dipakai masyarakat perkotaan untuk keperluan sehari hari ini, pada umumnya $80 \%$ menjadi air limbah yang dikenal dengan air limbah domestik yang merupakan masalah terhadap lingkungan. Contoh konkritnya adalah sering dijumpainya ikan-ikan yang mati di teluk. Timbulnya bau busuk dan warna hitam terutama di musim kemarau di sungai-sungai di kota besar.

Disisi lain air limbah juga dapat sebagai 
potensi untuk air baku penyediaan air bersih di perkotaan. Sebagai contoh DKI Jakarta, diperkirakan tahun 2010 membuang air limbah domestik sebanyak 2,6 juta $\mathrm{m}^{3}$ per hari (JICA, 1990). Bila air dalam jumlah sebesar ini dilakukan pengolahan menjadi air daur ulang, maka permasalahan pencemaran lingkungan dan krisis air bersih secara bersamaan akan dapat tertangani.

\section{ATURAN YANG MENDUKUNG DAUR ULANG AIR LIMBAH}

Di dalam meningkatkan penerapan daur ulang air limbah, Pemerintah Indonesia telah menerbitkan beberapa aturan walaupun dalam beberapa hal perlu ditambah atau disempurnakan. Aturan tersebut diantaranya adalah:

a. Undang-Undang No. 32 Tahun 2009 tentang Perlindungan dan Pengelolaan Lingkungan Hidup.

b. Instruksi Presiden Nomor 2 tahun 2008 tentang penghematan air dan energi.

c. Peraturan Pemerintah No 42 tahun 2008, tentang sumber daya air.

d. Peraturan Menteri Pekerjaan Umum Nomor 6 tahun 2011 tentang pengelolaan sumber daya air, dimana pada pasal 37 ayat 1 menyebutkan bahwa daur ulang air limbah wajib dilakukan oleh pengguna air dalam jumlah besar, hotel, restoran, rumah sakit dan industri dengan membangun instalasi daur ulang.

e. Dokumen negara" Indonesia's Technology Need Assessment for Climate Change Adaptation 2012.

\section{PROSES DAUR ULANG AIR LIMBAH}

Air limbah domestik, untuk dapat dipergunakan kembali atau di daur ulang, harus melalui tahapan proses sesuai dengan penggunaan yang diinginkan. Tahapan tersebut meliputi:

a. Pengumpulan air limbah.

Sumber limbah domestik di perkantoran atau gedung umumnya terpencar-pencar dan cukup jauh letaknya, sehingga diperlukan suatu sistem pengumpulan air limbah. Sistem Pengumpulan ini dilakukan dengan gravitasi. Namum bila rumah sakit sudah terbangun dan saluran air limbah masih tercampur dengan air hujan, maka perlu pemisahan dan pembuatan saluran baru. Bila dilakukan dengan grafitasi akan menimbulkan biaya besar dan tingkat kesulitan tinggi. Untuk kasus seperti ini, pengumpulan air limbah dilakukan dengan sistem perpompaan.

b. Pengolahan air limbah.

Air limbah dari sumber yang telah terkumpul, diproses dengan menggunakan Instalasi
Pengolahan Air Limbah dengan Instalasi Pengolahan Air Limbah (IPAL) sampai memenuhi baku mutu lingkungan. Teknologi pengolahan air limbah yang dapat diaplikasikan untuk air limbah domestik ada berbagai macam diantaranya adalah:

Teknologi Proses Lumpur Aktif

> Teknologi Proses Fisika Kimia Koagulasi, Flokulasi dan Sedimentasi.

$>$ Teknologi Proses Rotating Biological Contactor

$>$ Teknologi Proses Trickling Filter.

$>$ Teknologi Proses Biofilter Anaerob-aerob.

$>$ Teknologi Membran.

c. Pengolahan Akhir untuk Daur Ulang Air Limbah. Proses ini diterapkan untuk memastikan bahwa air yang akan digunakan kembali memenuhi peruntukannya. Teknologinya ada berbagai macam tergantung dari kualitas air yang diinginkan.

Teknologi Daur Ulang Air Limbah Domestik dapat menggunakan metode yang sederhana, seperti penggunaan saringan pasir dan karbon atau dengan metode yang lebih modern, yakni dengan menggunakan sistem membran maupun dengan resin ion exchange.

Air daur ulang limbah domestik, dapat dimanfaatkan untuk berbagai penggunaan diantaranya adalah untuk:

a. Siram tanaman.

Penggunaan air untuk siram taman ini cukup besar, dapat mencapai antara 5-10 liter per $\mathrm{m}^{2}$. Secara umum kualitas air limbah domestik tidak lah bermasalah bila langsung dipergunakan untuk penyiraman tanaman. Namun perlu diwaspadai akan bahaya bila meresap dan mencemari air sumur dangkal. Sehingga ada persyaratan air yang diperbolehkan untuk siram tanaman seperti yang diatur pada PP No. 20 tahun 1990 pasal Kriteria Penggunaan Air (Anonim 2, 1990).

b. Pencucian kendaraan.

Untuk air kategori ini tidak memerlukan kualitas air bersih atau air minum. Yang terpenting air tidak terkontaminasi minyak, garam atau zat kimia lain yang dapat menimbulkan karat.

c. Flushing atau penggelontoran toilet.

Kuaitas air flushing toilet ini juga tidak harus sampai air bersih. Dalam penggunaan air daur ulang untuk flushing toilet, perpipaan air flushing dengan air bersih harus terpisah. Untuk itu bangunan-bangunan baru seyogyanya sudah harus membuat pemisahan perpipaan seperti ini untuk dapat memanfaatkan air daur ulang 
guna mengantisipasi krisis air.

d. Kebutuhan MCK.

Untuk kebutuhan mandi, cuci dan kakus ini memerlukan kualitas air yang memenuhi standar air bersih yakni mengikuti Permenkes No. 407 tahun 2002. Agar supaya air limbah dapat mencapai kualitas ini, perlu aplikasi teknologi pengolahan yang memadai.

e. Air pendingin mesin.

Untuk keperluan ini air daur ulang harus jernih, tidak menimbulkan karat dan tidak menimbulkan penyumbatan pada saluran pendingin.

\subsection{Teknologi daur ulang air limbah}

\subsubsection{Teknologi Sederhana Saringan Pasir Lambat}

Sistem saringan pasir lambat merupakan teknologi pengolahan air yang sangat sederhana dan produknya air bersih dengan kualitas yang cukup baik. Sistem saringan pasir lambat ini mempunyai keunggulan antara lain tidak memerlukan bahan kimia (koagulan), yang mana bahan kimia ini merupakan kendala yang sering dialami pada proses pengolahan air di daerah terpencil. Gambar sistem pengolahan air untuk daur ulang air limbah dengan sistem saringan pasir lambat ditunjukkan pada Gambar 1.

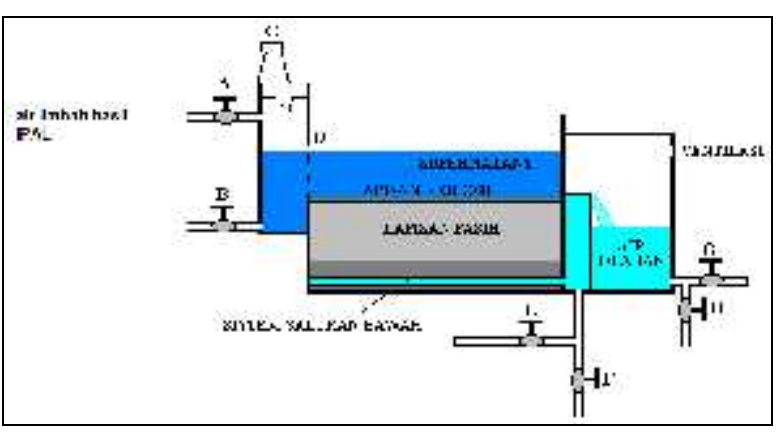

Gambar 1 : Skema Proses Saringan Pasir Lambat.

Di dalam sistem pengolahan ini proses pengolahan yang utama adalah penyaringan dengan media pasir dengan kecepatan penyaringan 4 - 6 $\mathrm{m}^{3} / \mathrm{m}^{2} /$ hari (Herlambang, 2001). Air yang akan diolah (air baku) dialirkan ke tangki penerima, kemudian dialirkan ke bak pengendap tanpa memakai zat kimia untuk mengendapkan kotoran yang ada dalam air baku. Selanjutnya di saring dengan saringan pasir lambat. Setelah disaring dilakukan proses khlorinasi dan selanjutnya ditampung di bak penampung air bersih, seterusnya di alirkan ke konsumen.

Jika air hasil olahan IPAL dialirkan ke saringan pasir lambat, maka kotoran-kotoran melayang yang ada di dalamnya akan tertahan pada media pasir. Oleh karena adanya akumulasi kotoran baik dari zat organik maupun zat anorganik, maka pada media filternya akan terbentuk lapisan (film) biologis. Dengan terbentuknya lapisan ini maka di samping proses penyaringan secara fisika dapat juga menghilangkan kotoran (impuritis) secara bio-kimia. Biasanya amoniak dengan konsetrasi yang rendah, zat besi, mangan dan zat-zat yang menimbulkan bau dapat dihilangkan dengan cara ini. Hasil dengan cara pengolahan ini mempunyai kualitas yang baik.

Cara ini sangat sesuai untuk pengolahan air daur ulang yang mempunyai kekeruhan yang rendah dan relatif tetap. Biaya operasional dan perawatannya rendah, karena pada proses pengendapan biasanya tanpa bahan kimia. Tetapi jika kekeruhan air baku cukup tinggi, pengendapan dapat juga memakai bahan kimia (koagulan) agar beban filter tidak terlalu berat.

\subsubsection{Teknologi Saringan Multi Media}

Proses pengolahan air daur ulang dengan sistem saringan multimedia ditampilkan pada Gambar 2. Saringan multi media ini dapat dipergunakan untuk mengolah air hasil olahan IPAL yang dapat menghasilkan kualitas air hasil olahan lebih bagus dibanding saringan pasir lambat. Media yang dipergunakan adalah pasir silika, karbon aktif dan mangan zeolit. Proses pengolahan air daur ulang dengan saringan multi media ini dilakukan dengan cara sebagai berikut.

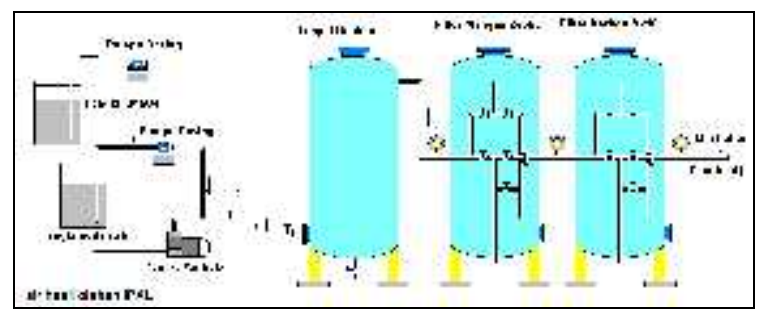

Gambar 2 : Skema Proses Saringan Multimedia.

Air limbah hasil olahan IPAL dipompa dengan menggunakan pompa jet, sambil diinjeksi dengan larutan khlorin atau kaporit dialirkan ke tangki reaktor. Khlorin berfungsi untuk mengoksidasi organik, besi dan mangan yang masih tersisa di dalam air limbah. Dari tangki reaktor air dialirkan ke saringan pasir cepat untuk menyaring oksida besi atau oksida mangan yang terbentuk di dalam tangki reaktor. Setelah disaring dengan saringan pasir, air dialirkan ke filter mangan zeolit. Filter mangan zeolit berfungsi untuk menghilangkan zat besi atau mangan yang belum sempat teroksidasi oleh khlorin atau kaporit. Selanjutnya terakhir melewati filter karbon yang berfungsi untuk menyerap bau dan warna. 
Dengan filtrasi seperti ini, air hasil olahan sudah dapat dipergunakan kembali sebagai air siram taman atau pun air flushing toilet.

\subsubsection{Teknologi Filtrasi Membran}

Membran adalah struktur lembaran tipis yang lentur bisa terbuat dari polimer, plat stainless dan lain sebagainya. Teknologi pengolahan air menggunakan membran sebenarnya bukanlah suatu teknologi yang baru ditemukan, karena membran itu sendiri telah digunakan semenjak lebih dari 50 tahun yang lalu. Adapun jenis membran yang tersedia saat ini dibagi menjadi 4 kelompok besar disesuaikan dengan ukuran dari tingkat penyaringan atau sering disebut dengan istilah "Filtration degree" seperti pada Gambar 3 (Degreemont, 1991).

Tingkat-tingkat penyaringan yang dimaksud adalah:

- Micro Filtration (MF)

- Ultra Filtration (UF)

- Nano Filtration (NF)

- Hyper Filtration / Reverse Osmosis (RO)

\begin{tabular}{|c|c|c|c|}
\hline $\begin{array}{l}\text { Reverse } \\
\text { Dramosis }\end{array}$ & Nanafiltration & Ultrafiltration fur & Uniorofiltration \\
\hline 0 o[x]1 & 口 ז01 & $\begin{array}{l}\text { Microlls } \\
\text { त. [:1 }\end{array}$ & 0 \\
\hline $\begin{array}{l}\text { Nor ov日lemt } \\
\text { Salts }\end{array}$ & $\begin{array}{l}\text { Civaltant } \\
\text { Bistt: } \\
\text { Bugdis }\end{array}$ & 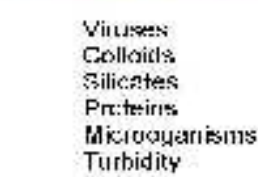 & $\begin{array}{l}\text { Eusperulet| } \\
\text { Mat:urial }\end{array}$ \\
\hline
\end{tabular}

Gambar 3 : Tingkatan Filtrasi Berdasarkan Ukuran Pori-Pori Membran.

Sesuai dengan nama dan tingkatan dari 'Filtration Degree", tentunya diharapkan akan didapat air dengan tingkat kebersihan tertentu pula. Misalnya, pada Micro Filtration (MF) dengan Filtration Degree sekitar 1 mikron, diharapkan sebagian besar dari suspended material (padatan melayang) akan tersaring. Dan sudah bukan menjadi suatu hal yang baru bahwa dengan menggunakan teknologi membran ini pulalah telah dimungkinkan untuk merubah air laut menjadi air tawar, yaitu dengan menggunakan membran Reverse Osmosis (RO).

Dari ke empat kategori membran tersebut, yang paling banyak dipergunakan untuk sistem daur ulang adalah membran ultra filtrasi dan reverse osmosis.

\subsubsection{Daur Ulang Air Limbah dengan Sistem Ultra Filtrasi}

Ultra filtrasi merupakan teknologi penyaringan air dengan menggunakan membran untuk memisahkan senyawa maupun partikel koloid, protein, polutan dari unsur microbiologis yang ada pada air baku. Ukuran membran ultra filtrasi sangat kecil sehingga dapat memisahkan material tersuspensi, bakteri, virus dan pathogen. Semua partikel dengan ukuran kisaran 0,01 mikron sampai dengan 0,1 mikron akan dapat terpisah dengan teknologi ultra filtrasi. Tekanan operasi pada sistem ultra filtrasi dapat digunakan tekanan rendah yaitu antara 0,5 sampai 3 bar. Membran ultra filtrasi dapat dibuat dalam beberapa tipe modul seperti hollow fiber, lembaran rata dan dalam bentuk tabung. Tipe hollow fiber adalah tipe yang paling banyak dipakai karena akan dapat menghasilkan permukaan filtrasi yang besar. Kecepatan filtrasi akan sangat tergantung dari luas permukaan filter. Dengan semakin besarnya luas permukaan filter, maka produktifitas air olahan akan semakin besar.

Pengolahan air permukaan konvensional yang sering digunakan saat ini adalah dengan proses penambahan bahan kimia, yaitu koagulasi-flokulasi dan dilanjutkan dengan proses sedimentasi menggunakan clarifier, kemudian disaring menggunakan filter pasir (sand filter). Jika dibandingkan dengan proses pengolahan air konvensional, teknologi ultra filtrasi mempunyai beberapa keunggulan seperti, kualitas produknya tetap tidak tergantung dari kualitas air baku, lumpur yang dihasilkan dari produksi relatif sedikit, tidak menggunakan bahan kimia koagulan dan flokulan untuk memisahkan partikel padat tersuspensi dalam air, serta kebutuhan lahan untuk pembangunan unit relatif kecil. Ultra filtrasi juga tidak menghasilkan banyak lumpur sebagai produk samping.

Tabel 2 : Perbandingan Teknologi Ultrafiltrasi Dan Teknologi Konvensional.

\begin{tabular}{|c|c|c|}
\hline Tipe & Ultrafiltrasi & $\begin{array}{c}\text { Teknologi } \\
\text { konvensional }\end{array}$ \\
\hline Kualitas produk & Tetap & $\begin{array}{l}\text { Naik turun tergantung } \\
\text { kualitas air baku }\end{array}$ \\
\hline Pengoperasian & mudah & Relatif susah \\
\hline Sludge & $\begin{array}{l}\text { Tdk ada } \\
\text { penambahan }\end{array}$ & Ada produksi lumpur \\
\hline Bahan Kimia & Tidak diperlukan & Diperlukan \\
\hline $\begin{array}{l}\text { Kebutuhan } \\
\text { lahan }\end{array}$ & Kecil & Besar \\
\hline
\end{tabular}




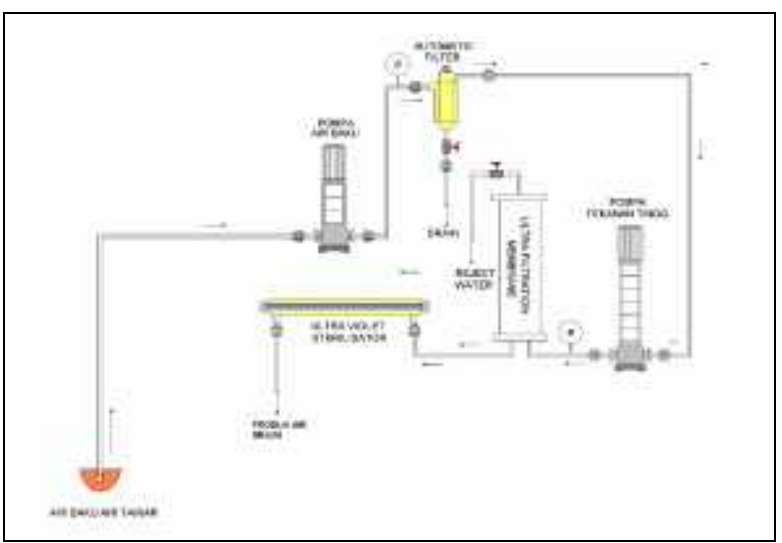

Gambar 4 : Skema Proses Pengolahan Air Limbah Dengan Membran Ultra Filtrasi (Nugroho,2009) .

Air baku yang berasal dari air hasil olahan IPAL dan lain sebagainya dipompa ke unit pre-treatment untuk menghilangkan padatan tersuspensi. Kalau pada sistem konvensional, unit pre-treatment ini menggunakan bak pengendap yang prosesnya memerlukan penambahan bahan kimia koagulan dan flokulan, sedangkan pada sistem ultra filtrasi, digunakan filter Amiad.

Filter amiad seperti pada Gambar 5 merupakan teknologi baru untuk memisahkan kotoran maupun lumpur dalam air baku. Amiad terdiri dari filter yang terbuat dari membran stainless steel dengan bermacam-macam ukuran, casing baja serta motor dan pompa. Amiad bekerja secara otomatis. Air baku dipompa ke dalam filter secara kontinyu untuk dilakukan proses filtrasi. Apabila filter sudah kotor, tekanan dalam filter akan naik sampai tingkat tertentu sesuai pengaturan. Pada saat tekanan sudah mencapai tingkat tertentu, maka saklar otomatis akan bekerja menggerakkan motor untuk melakukan backwash. Pada saat backwash, lumpur atau padatan tersuspensi yang menempel pada bagian filter akan terdorong keluar bersama aliran backwash. Proses filtrasi dan backwash berjalan secara otomatis, sehingga akan sangat mempermudah kerja dari operator.

Setelah melalui proses pre-treatment, air selanjutnya dipompa masuk ke membran ultra filtrasi. Di unit membran ini dapat diset besarnya air produk dan besarnya air rijek. Semakin besar rijek, maka kualitas air produk akan semakin baik. Proses backwash pada sistem ultra filtrasi dapat diatur secara manual atau secara otomatis. Pengesetan backwash secara manual dapat dilakukan seperti pada filter konvensional dengan sistem buka tutup katup apabila penurunan tekanan filter sudah tinggi. Pengesetan backwash secara otomatis dapat dilakukan dengan memasang alat kontrol tekanan dan katup otomatis. Apabila tekanan sudah mencapai angka tertentu, maka proses backwash akan berjalan dengan sendirinya.
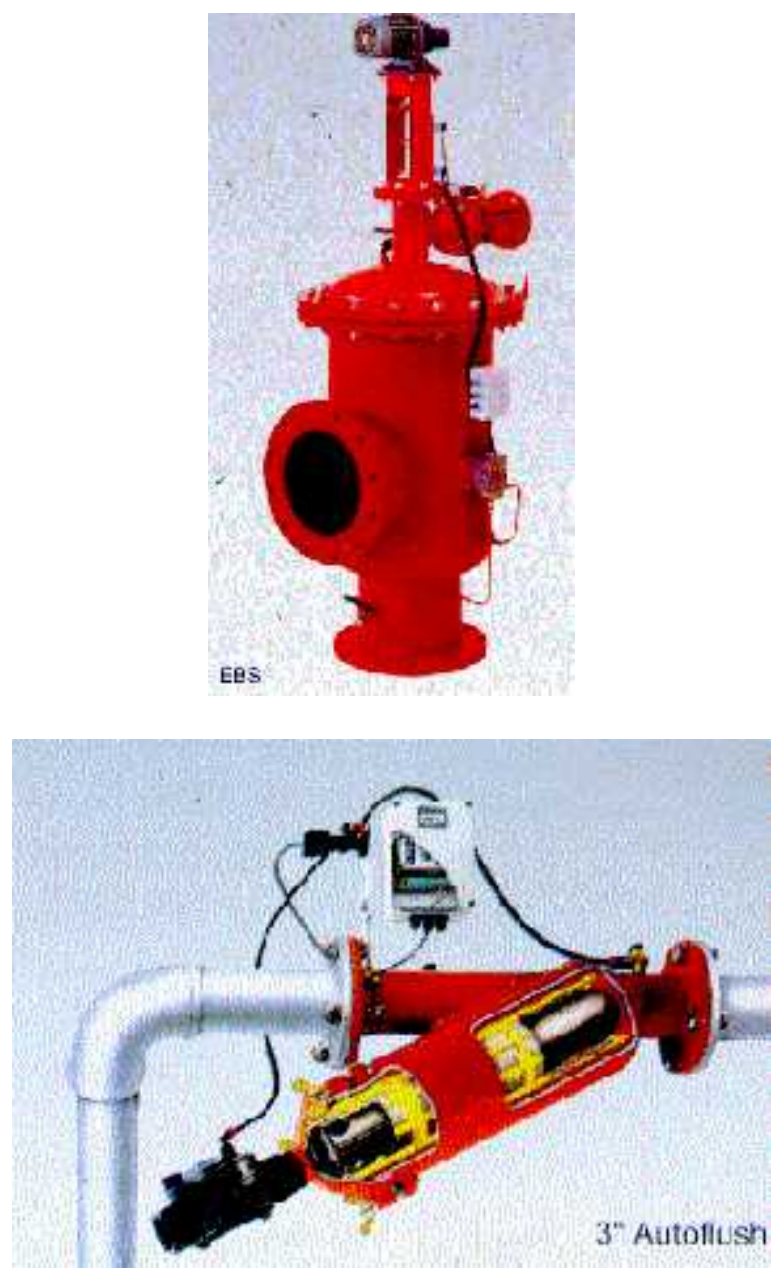

Gambar 5 : Unit Filter Amiad.

Walaupun secara teori ultra filtrasi dapat menahan kontaminan mikrobiologis seperti virus dan bakteri coli, untuk lebih amannya perlu juga ditambah unit desinfeksi menggunakan UV atau khlorin. Contoh rangkaian unit pengolah air ultrafiltrasi dan air hasil olahannya adalah seperti pada Gambar 6.

\subsubsection{Daur Ulang Air Limbah Dengan Sistem Reverse Osmosis (RO)}

Apabila dua buah larutan dengan konsentarsi encer dan konsentrasi pekat dipisahkan oleh membran semi permeabel, maka larutan dengan konsentrasi yang encer akan terdifusi melalui membran semi permeabel tersebut masuk ke dalam larutan yang pekat sampai terjadi kesetimbangan konsentarsi. Fenomena tersebut dikenal sebagai proses osmosis. Sebagai contoh misalnya, jika air tawar dan air laut (asin) dipisahkan dengan membran semi permeabel, maka air tawar akan terdifusi ke dalam air asin melalui membran semi permeabel tersebut sampai terjadi kesetimbangan. 

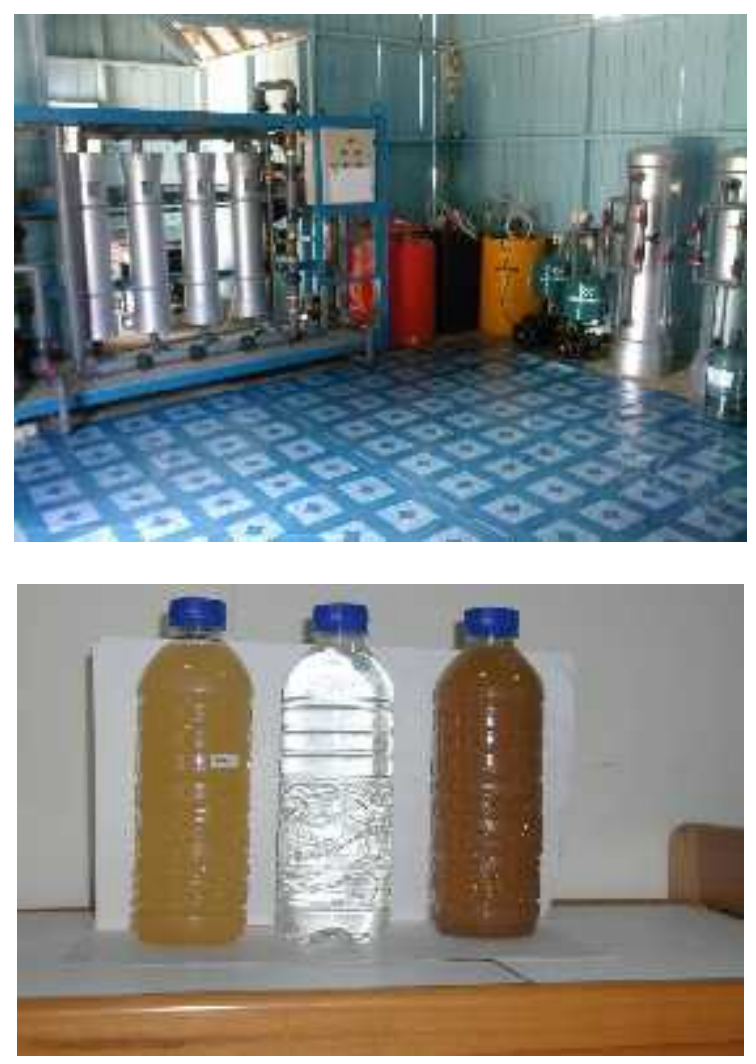

Gambar 6 : Contoh Aplikasi Ultra Filtrasi dan Visual Air.

Daya penggerak (driving force) yang menyebabkan terjadinya aliran /difusi air tawar ke dalam air asin melalui membran semi permeabel tersebut dinamakan tekanan osomosis. Besarnya tekanan osmosis tersebut tergantung dari karakteristik membran, temperatur air, dan konsentrasi garam yang terlarut dalam air. Tekanan osmotik normal air-laut yang mengandung TDS $35.000 \mathrm{ppm}$ dan suhu $25^{\circ} \mathrm{C}$ adalah kira-kira 26,7 $\mathrm{kg} / \mathrm{cm}^{2}$, dan untuk air laut di daerah timur tengah atau laut Merah yang mengandung TDS 42,000 ppm, dan suhu $300^{\circ} \mathrm{C}$, tekanan osmotik adalah $32,7 \mathrm{~kg} / \mathrm{m}^{2}$ (Degreemont, 1991).

Apabila pada suatu sistem osmosis tersebut, diberikan tekanan yang lebih besar dari tekanan osmosisnya, maka aliran air tawar akan berbalik yakni dari air asin ke air tawar melalui membran semi permeabel, sedangankan garamnya tetap tertinggal di dalam larutan garammya, sehingga menjadi lebih pekat. Proses tersebut dinamakan osmosis balik (reverse osmosis). Prinsip dasar proses osmosis dan proses osmosis balik tersebut ditunjukkan seperti pada Gambar 7.

Teknologi pengolahan dengan RO ini merupakan teknologi yang paling baik untuk diterapkan pada proses daur ulang air limbah. Dengan pori-pori yang sangat kecil yang memungkinkan partikel untuk tertahan, maka kualitas air hasil proses dengan sistem RO ini dijamin dapat dipergunakan untuk keperluan air bersih maupun air minum secara aman. Namun demikian, sisi lemah dari teknologi RO ini adalah persyaratan air yang boleh melewati membran ini sangat ketat, sehingga perlu pengolahan awal yang lebih baik. Demikian pula karena tekanan pada proses filtrasi dengan sistem RO ini cukup tinggi, maka energi listrik yang dibutuhkan jauh lebih besar dibanding bila menggunakan sistem filtrasi biasa.

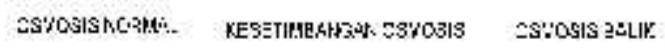

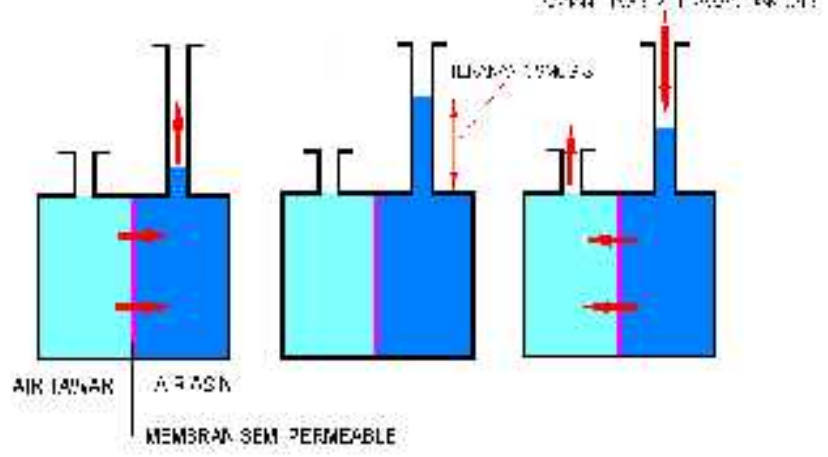

Gambar 7: Prinsip Dasar Proses Osmosis Balik (Reverse Osmosis).

Contoh kasus adalah daur ulang air limbah domestik dengan menggunakan sistem reverse osmosis adalah seperti yang ada di salah satu perkantoran di Jakarta. Air limbah domestik yang keluar dari semua sumber di perkantoran tersebut dikumpulkan dan diolah dengan menggunakan IPAL sistem lumpur aktif dan biofilter anaerob-aerob. Hasil olahan IPAL ini dilakukan proses lebih lanjut dengan instalasi daur ulang. Flow diagram instalasi daur ulang dapat dilihat pada Gambar 8. (Lampiran).

Sebagaimana terlihat pada Gambar 8 tersebut, sebagai pre-treatment air sebelum masuk ke membran RO dilakukan dengan menginjeksikan air limbah dengan oksidator khlor atau kalium permanganat untuk mengoksidasi organik maupun polutan logam seperti besi dan mangan. Setelah itu air dipompa melalui filter multimedia yang berisi pasir, karbon dan manganese. Sebelum disaring dengan RO, terlebih dahulu air dilewatkan melalui filter cartridge dengan ukuran pori 5 mikron, untuk menjamin kualitas air yang masuk ke sistem RO sudah terbebas dari suspended solid. Setelah melalui filter cartridge, air dipompa dengan pompa tekanan tinggi untuk disaring dengan membran RO. Hasil proses daur ulang air dengan menggunakan sistem RO ini sangat bagus, bahkan kualitasnya melebihi air hasil produksi PDAM seperti yang ditunjukkan pada Tabel 3. 
Tabel 3 : Kualitas Air Daur Ulang Dengan Teknologi Membran.

\begin{tabular}{|c|c|c|c|c|}
\hline No & PARAMETER & SATUAN & $\begin{array}{l}\text { BAKU } \\
\text { MUTU }\end{array}$ & HASIL \\
\hline A & FISIKA & & & \\
\hline 1 & Bau & - & $\begin{array}{l}\text { Tidak } \\
\text { berbau }\end{array}$ & $\begin{array}{c}\text { sedikit } \\
\text { berbau } \\
\text { clor }\end{array}$ \\
\hline 2 & $\begin{array}{l}\text { Zat Padat Terlarut } \\
\text { (TDS) }\end{array}$ & $\mathrm{mg} / \mathrm{l}$ & 1500 & 15 \\
\hline 3 & Kekeruhan & NTU & 25 & $<1$ \\
\hline 4 & Rasa & - & $\begin{array}{c}\text { Tidak } \\
\text { berasa }\end{array}$ & $\begin{array}{l}\text { Tidak } \\
\text { berasa }\end{array}$ \\
\hline 5 & Suhu & $\mathrm{OC}$ & $\begin{array}{c}\text { Udara +- } \\
\text { 3oC }\end{array}$ & 26,0 \\
\hline 6 & Warna & Pt-Co & 50 & $<1$ \\
\hline B & KIMIA & & & \\
\hline 1 & $\mathrm{pH}$ & - & $6,5-9,0$ & 6,5 \\
\hline 2 & Air raksa $(\mathrm{Hg})$ & $\mathrm{mg} / \mathrm{l}$ & 0,001 & $<0,0005$ \\
\hline 3 & Arsen (As) & $\mathrm{mg} / \mathrm{l}$ & 0,05 & $<0,005$ \\
\hline 4 & Besi (Fe) & $\mathrm{mg} / \mathrm{l}$ & 1,0 & $<0,06$ \\
\hline 5 & Fluorida (F) & $\mathrm{mg} / \mathrm{l}$ & 1,5 & 0,17 \\
\hline 6 & Kadmium (Cd) & $\mathrm{mg} / \mathrm{l}$ & 0,005 & $<0,003$ \\
\hline 7 & $\begin{array}{l}\text { Kesadahan total } \\
\left(\mathrm{CaCO}_{3}\right)\end{array}$ & $\mathrm{mg} / \mathrm{l}$ & 500 & $<2$ \\
\hline 8 & Klorida (Cl) & $\mathrm{mg} / \mathrm{l}$ & 600 & 7,9 \\
\hline 9 & Khromium $\left(\mathrm{Cr}^{6+}\right)$ & $\mathrm{mg} / \mathrm{l}$ & 0,05 & $<0,01$ \\
\hline 10 & Mangan (Mn) & $\mathrm{mg} / \mathrm{l}$ & 0,5 & $<0,02$ \\
\hline 11 & Nitrat $\left(\mathrm{NO}_{3}-\mathrm{N}\right)$ & $\mathrm{mg} / \mathrm{l}$ & 10 & $<0,2$ \\
\hline 12 & Nitrit $\left(\mathrm{NO}_{2}-\mathrm{N}\right)$ & $\mathrm{mg} / \mathrm{l}$ & 1,0 & $<0,02$ \\
\hline 13 & Selenium (Se) & $\mathrm{mg} / \mathrm{l}$ & 0,01 & $<0,002$ \\
\hline 14 & Seng (Zn) & $\mathrm{mg} / \mathrm{l}$ & 15 & $<0,01$ \\
\hline 15 & Cyanida (CN) & $\mathrm{mg} / \mathrm{l}$ & 0,1 & $<0,005$ \\
\hline 16 & Sulfat $\left(\mathrm{SO}_{4}\right)$ & $\mathrm{mg} / \mathrm{l}$ & 400 & $<0,03$ \\
\hline 17 & $\begin{array}{l}\text { Surfactan anion } \\
\text { (MBAS) }\end{array}$ & $\mathrm{mg} / \mathrm{l}$ & 0,5 & $<0,01$ \\
\hline 18 & Timbal (Pb) & $\mathrm{mg} / \mathrm{l}$ & 0,05 & $<0.01$ \\
\hline 19 & $\begin{array}{l}\text { Nilai } \\
\text { Permanganat }\end{array}$ & $\mathrm{mg} / \mathrm{l}$ & 10 & $<0,2$ \\
\hline C & MIKROBIOLOGI & & & \\
\hline 1 & Total Koliform & MPN/100ml & 50 & 0 \\
\hline
\end{tabular}

\section{KENDALA PENERAPAN DAUR ULANG AIR LIMBAH}

Dalam menerapkan daur ulang air limbah, sampai dengan saat ini masih banyak mengalami kendala (Anonim 1, 2011). Kendala yang terbesar adalah dari sisi persepsi masyarakat dan psikologis. Kebanyakan masyarakat belum dapat menerima untuk menggunakan air bila mengetahui sumbernya dari air limbah. Secara umum kendala-kendala penggunaan air daur ulang adalah sebagai berikut:

1) Adanya standar kualitas yang harus dipenuhi. Standar kualitas tergantung dari peruntukan air daur ulang tersebut. Bila digunakan untuk pertanian dan siram taman maka standarnya memenuhi aturan yang sudah ditetapkan pemerintah. Sebagai contoh untuk DKI Jakarta air siram taman standar kualitasnya sesuai dengan Pergub 582 tahun 1995.

2) Adanya kemungkinan dampak jangka panjang terhadap kesehatan bila menggunakan air daur ulang karena kualitas yang masih belum memenuhi syarat ditunjang dengan adanya dugaan adanya polutan yang masih terkandung dalam air.

3) Persepsi negatif dari masyarakat yang secara psikologis masih belum dapat menerima/memakai air daur ulang mengingat sumbernya dari limbah manusia.

4) Biaya pengolahan air limbah menjadi air bersih yang relatif lebih tinggi. Air limbah, kualitasnya lebih buruk daripada air sungai yang biasa dipergunakan sebagai air baku PAM. Dengan buruknya kualitas air baku yang menggunakan air limbah, maka untuk mencapai kualitas air olahan sesuai standar air minum, diperlukan biaya pengolahan yang lebih tinggi. Dampaknya adalah harga jual produk akan lebih mahal.

5) Ada sebagian masyarakat yang menganggap bahwa air daur ulang itu najis, karena sumbernya dari air limbah kotoran manusia.

Secara lebih spesifik lagi, kendala penerapan daur ulang air limbah dapat dilihat pada tabel $4 .^{(12)}$ Tabel tersebut menampilkan kendala penyebab dan bagaimana cara mengatasinya. Kendala ini dikelompokkan dari aspek ekonomi, peraturan, institusional, sosial, kapasitas dan hak kekayaan intelektual.

\section{PENUTUP}

Dalam melakukan antisipasi krisis air yang timbul akibat dari fenomena perubahan iklim global, metode daur ulang air limbah cukup tepat untuk dilakukan. Metode daur ulang air ini ada berbagai cara dari mulai yang sederhana dengan penyaringan menggunakan pasir sampai yang cukup canggih yakni dengan sistem membran dan cara ini diterapkan tergantung dari tujuan penggunaan air daur ulang itu sendiri. Dalam penerapan air daur ulang banyak ditemui kendala-kendala dari aspek ekonomi, peraturan, sosial dan lain sebagainya. Kendalakendala ini perlu dicarikan solusinya sehingga penerapan daur ulang air ini aman dapat memasyarakat secara luas yang pada akhirnya diharapkan dapat meminimalkan resiko krisis air dimasa mendatang.

\section{DAFTAR PUSTAKA}

- Anonim 1. "Republic of Indonesia, Indonesia's Technology Needs Assessment for Climate Change Adaptation, Synthesis Report, February 2012.

- Anonim 2. "Peraturan Pemerintah No 20 tahun 1990 tentang pengendalian Pencemaran Air". 1990. 
- Anonim 3. "Instruksi Presiden Nomor 2 tahun 2008 tentang penghematan air dan energi". 2008.

- Anonim 4. "Peraturan Menteri Pekerjaan Umum Nomor 6 tahun 2011 tentang pengelolaan sumber daya air", 2011.

- Anonim 4. "Peraturan Pemerintah No 42 tahun 2008, tentang sumber daya air". 2008.

- Anonim 4. "Undang-undang Nomor 32 tahun 2009 tentang Perlindungan dan Pengelolaan Lingkungan Hidup", 2009.

- Degreemont. "Water Treatment Handbook", Sixth edition, 1991

- Herlambang, Arie. "Aplikasi Teknologi Sarpalam 100 UF untuk Penyediaan Air Bersih di Dusun Dantar, Padang Cermin, Lampung", Jurnal Teknologi Lingkungan, Vol.2, No. 2, Mei 2001.

- JICA., "The Studi On Urban Drainage and Wastewater Disposal Project in The City of Jakarta". 1990

- Metcalf and Eddy, Waste Water Engineering, Mc Graw Hill 1978.
- Nugroho, Rudi dan kawan. "Buku Panduan Efisiensi Pemanfaatan Sumber daya Air Pandeglang", BPPT 2011.

- Nugroho, Rudi. "Pengolahan Air Limbah Domestik di Kota Metropolitan". Makalah Sosialisasi Sanitasi Berbasis Masyarakat di Kota Administrasi Jakarta Timur, Juni 2011.

- Nugroho, Rudi. "Teknologi Pengolahan Air dengan Membran dan Desalinasi", Modul Pelatihan Teknologi Pengolahan Air Bersih, BPPT. 2009. 
Tabel 1 : Karakteristik Air Limbah Domestik.

\begin{tabular}{|c|c|c|c|c|}
\hline \multirow{2}{*}{ Kontaminan } & \multirow{2}{*}{ Satuan } & \multicolumn{3}{|c|}{ Kelas dan Konsentrasi } \\
\hline & & Lemah & Sedang & Kuat \\
\hline Total Solid (TS) & $\mathrm{mg} / \mathrm{l}$ & 350 & 700 & 1200 \\
\hline - Terlarut, Total (TDS) & $\mathrm{mg} / \mathrm{l}$ & 250 & 500 & 850 \\
\hline Tetap & $\mathrm{mg} / \mathrm{l}$ & 195 & 300 & 525 \\
\hline Volatil & $\mathrm{mg} / \mathrm{l}$ & 105 & 200 & 325 \\
\hline - Padatan suspensi (SS) & $\mathrm{mg} / \mathrm{l}$ & 100 & 200 & 350 \\
\hline Tetap & $\mathrm{mg} / \mathrm{l}$ & 30 & 50 & 75 \\
\hline Volatil & $\mathrm{mg} / \mathrm{l}$ & 70 & 150 & 275 \\
\hline Padatan terendapkan & $\mathrm{mg} / \mathrm{l}$ & 5 & 10 & 20 \\
\hline $\mathrm{BOD}_{5}, 20^{\circ} \mathrm{C}$ & $\mathrm{mg} / \mathrm{l}$ & 100 & 200 & 300 \\
\hline TOC & $\mathrm{mg} / \mathrm{l}$ & 100 & 200 & 300 \\
\hline COD & $\mathrm{mg} / \mathrm{l}$ & 250 & 500 & 1000 \\
\hline Nitrogen (Total sbg N) & $\mathrm{mg} / \mathrm{l}$ & 20 & 40 & 85 \\
\hline - Organik & $\mathrm{mg} / \mathrm{l}$ & 8 & 15 & 35 \\
\hline - Ammonia bebas & $\mathrm{mg} / \mathrm{l}$ & 12 & 25 & 30 \\
\hline - Nitrit & $\mathrm{mg} / \mathrm{l}$ & 0 & 0 & 0 \\
\hline - Nitrat & $\mathrm{mg} / \mathrm{l}$ & 0 & 0 & 0 \\
\hline Pospor (Total sbg P) & $\mathrm{mg} / \mathrm{l}$ & 6 & 10 & 20 \\
\hline - Organik & $\mathrm{mg} / \mathrm{l}$ & 3 & 3 & 5 \\
\hline - Anorganik & $\mathrm{mg} / \mathrm{l}$ & 4 & 7 & 15 \\
\hline Klorida & $\mathrm{mg} / \mathrm{l}$ & 20 & 50 & 100 \\
\hline Sulfat & $\mathrm{mg} / \mathrm{l}$ & 20 & 30 & 50 \\
\hline Alkalinitas (sbg $\mathrm{CaCO}_{3}$ ) & $\mathrm{mg} / \mathrm{l}$ & 50 & 100 & 200 \\
\hline Lemak (Grease) & $\mathrm{mg} / \mathrm{l}$ & 50 & 100 & 150 \\
\hline Total coliform & $\mathrm{no} / 100 \mathrm{ml}$ & $10^{6}-10^{7}$ & $10^{7}-10^{8}$ & $10^{7}-10^{9}$ \\
\hline VOC & $\mu g / l$ & $<100$ & $100-400$ & $>400$ \\
\hline
\end{tabular}

Sumber: Metcalf and Eddy, 1978.
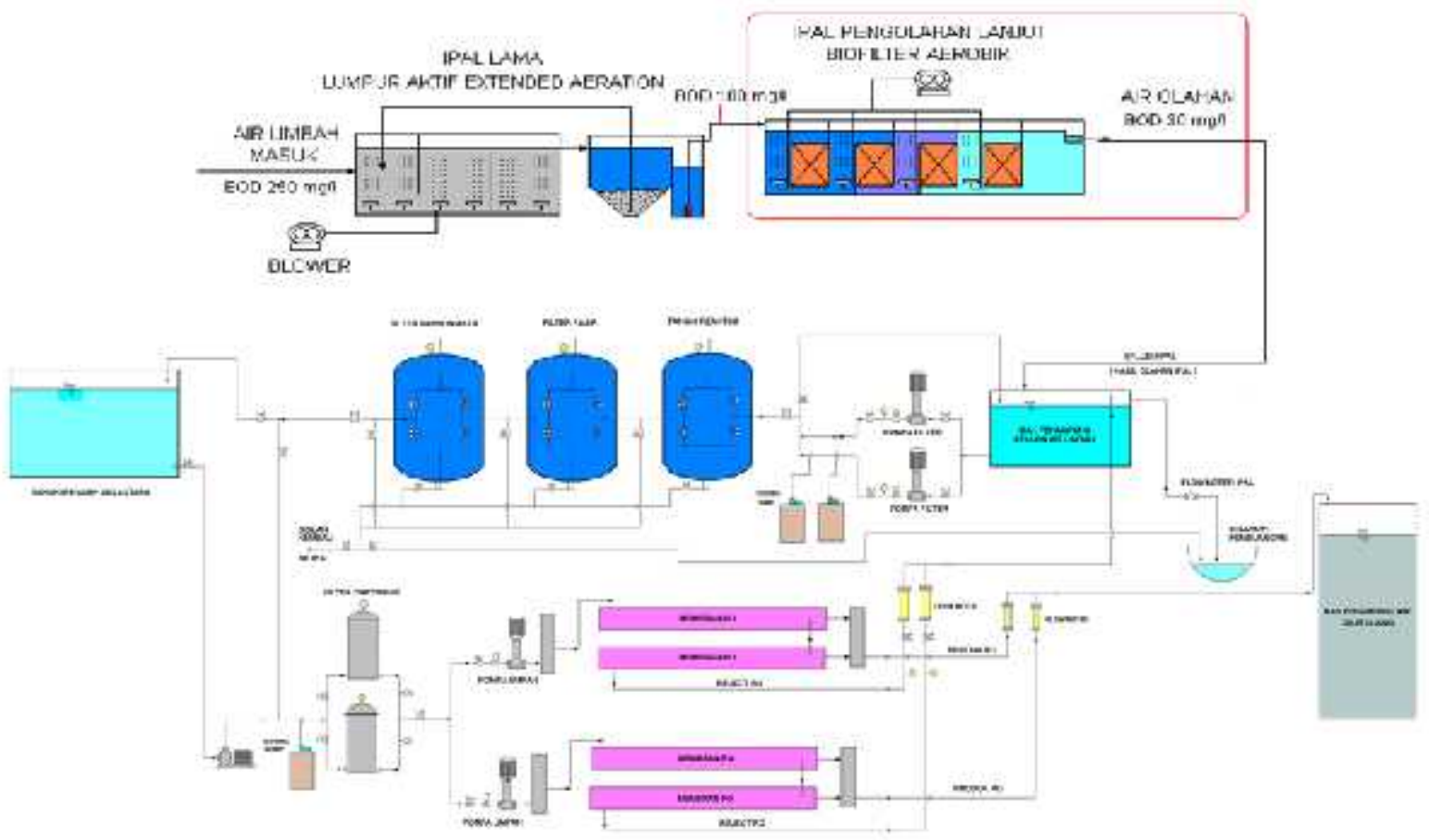

Gambar 8: Flow Diagram Instalasi Pengolahan Air Limbah Domestik Perkantoran Dengan Sistem RO. 
Tabel 4 : Kendala Kendala Dalam Penerapan Daur Ulang Air Limbah.

\begin{tabular}{|c|c|c|c|}
\hline HAMBATAN & HAMBATAN UTAMA & $\begin{array}{l}\text { PENYEBAN MUNCULNYA } \\
\text { HAMBATAN }\end{array}$ & $\begin{array}{ll}\text { UPAYA } & \text { MENGATASI } \\
\text { HAMBATAN } & \end{array}$ \\
\hline \multirow[t]{3}{*}{ EKONOMI } & $\begin{array}{l}\text { Tingginya modal untuk } \\
\text { pembangunan sistem daur ulang } \\
\text { air limbah menjadi air bersih }\end{array}$ & $\begin{array}{l}\text { Banyaknya peeralatan } \\
\text { unit pemroses yang } \\
\text { diperlukan } \\
\text { mengolah air limbah } \\
\text { domestic menjadi air } \\
\text { bersih }\end{array}$ & $\begin{array}{l}\text { Perlu dibuat aturan } \\
\text { perbankan tentang } \\
\text { pinjaman modal bunga } \\
\text { ringan untuk proyek daur } \\
\text { ulang air limbah }\end{array}$ \\
\hline & $\begin{array}{l}\text { Tidak adanya insentif keuangan } \\
\text { yang memadahi }\end{array}$ & $\begin{array}{l}\text { Pelaku usaha daur ulang } \\
\text { air limbah tidak } \\
\text { mendapat insentif } \\
\text { keringanan pajak atau } \\
\text { pinjaman bunga rendah }\end{array}$ & $\begin{array}{l}\text { Dibuat aturan menteri } \\
\text { keuangan tentang } \\
\text { pengurangan pajak atau } \\
\text { suku bunga rendah untuk } \\
\text { usaha daur ulang air } \\
\text { limbah }\end{array}$ \\
\hline & $\begin{array}{l}\text { Tingginya biaya operasional dan } \\
\text { perawatan instalasi pengolahan } \\
\text { daur ulang air limbah }\end{array}$ & 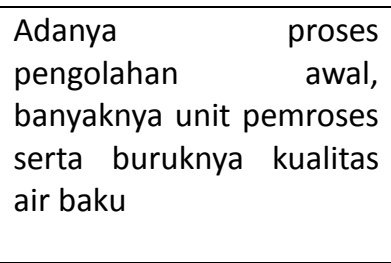 & $\begin{array}{lr}\text { Perlu diterbitkan } & \text { aturan } \\
\text { harga air daur ulang yang } \\
\text { memadahi } & \text { sehingga } \\
\text { operasional } & \text { dan } \\
\text { perawatan } & \text { dapat } \\
\text { berkelanjutan. } & \end{array}$ \\
\hline PERATURAN & $\begin{array}{l}\text { Masih kurangnya hokum dan } \\
\text { aturan tentang pelaksanaan daur } \\
\text { ulang air limbah }\end{array}$ & & $\begin{array}{l}\text { Ditambahkan aturan } \\
\text { seperti: setiap pelaku } \\
\text { usaha yang menghasilkan } \\
\text { limbah domestic, } \\
\text { prosentase tertentu } \\
\text { harus di daur ulang }\end{array}$ \\
\hline \multirow[t]{2}{*}{ KELEMBAGAAN } & $\begin{array}{l}\text { Kurangnya lembaga yang } \\
\text { melaksanakan program program } \\
\text { daur ulang air limbah }\end{array}$ & $\begin{array}{lr}\text { Program daur ulang air } \\
\text { limbah saat ini terbatas } \\
\text { dilakukan } r \text { oleh } \\
\text { kementerian } & \text { Pekerjaan } \\
\text { Umum } & \end{array}$ & $\begin{array}{l}\text { Perlu dibuat program } \\
\text { kegiatan daur ulang air } \\
\text { limbah yang lebih luas di } \\
\text { lembaga lain seperti di } \\
\text { Perindustrian, Pertanian } \\
\text { maupun Riset dan } \\
\text { Teknologi }\end{array}$ \\
\hline & $\begin{array}{l}\text { Belum adanya institusiyang } \\
\text { memberikan kelayakan akan } \\
\text { instalasi daur ulang maupun } \\
\text { produk dari daur ulang air limbah }\end{array}$ & $\begin{array}{l}\text { Belum adanya penugasan } \\
\text { secara lembaga dari } \\
\text { Pemerintah untuk } \\
\text { sertifikasi teknologi } \\
\text { maupun produk daur } \\
\text { ulang air }\end{array}$ & $\begin{array}{lr}\text { Perlu } & \begin{array}{r}\text { penugasan } \\
\text { pemerintah }\end{array} \\
\text { lembaga } & \text { sepada } \\
\text { Kementerian } & \\
\text { Perindustrian, atau Badan } \\
\text { Standarisasi Nasional } \\
\text { untuk mensertifikasi } \\
\text { instalasi dan produk daur } \\
\text { ulang air limbah. }\end{array}$ \\
\hline
\end{tabular}


Tabel 4 :(lanjutan).

\begin{tabular}{|c|c|c|c|}
\hline \multirow[t]{3}{*}{ SOSIAL } & $\begin{array}{l}\text { Kebiasaan masyarakat dalam } \\
\text { penggunaan air dan kurangnya } \\
\text { informasi akan produk daur ulang } \\
\text { air }\end{array}$ & $\begin{array}{l}\text { Untuk keperluan siram } \\
\text { taman dan lainya yang } \\
\text { tidak memerlukan air } \\
\text { kualitas bagus, } \\
\text { masyarakat terbiasa } \\
\text { menggunakan air PAM }\end{array}$ & $\begin{array}{l}\text { Perlu sosialisasi air daur } \\
\text { ulang dan kampanye } \\
\text { gerakan penggunaan air } \\
\text { daur ulang }\end{array}$ \\
\hline & $\begin{array}{l}\text { Munculnya persepsi negative } \\
\text { bahwa air daur ulang berbahaya } \\
\text { terhadap kesehatan }\end{array}$ & $\begin{array}{l}\text { Tidak ada informasi yang } \\
\text { cukup kepada masyarakat } \\
\text { tentang teknologi } \\
\text { pengolahan air dan air } \\
\text { daur ulang }\end{array}$ & $\begin{array}{l}\text { Perlu diberikan } \\
\text { pembelajaran sejak dini } \\
\text { melalui pendidikan } \\
\text { formal di sekolah tentang } \\
\text { kualitas air dan teknologi } \\
\text { pengolahan air. } \\
\text { Perlu dibangun } \\
\text { percontohan daur ulang } \\
\text { air limbah skala kawasan } \\
\text { di suatu permukiman }\end{array}$ \\
\hline & $\begin{array}{l}\text { Umat Muslim banyak yang } \\
\text { beranggapan bahwa air daur } \\
\text { ulang limbah tidak dapat } \\
\text { dipergunakan untuk wudhlu } \\
\text { (najis) }\end{array}$ & $\begin{array}{l}\text { Tidak adanya informasi } \\
\text { yang cukup tentang } \\
\text { kualitas air dan teknologi } \\
\text { pengolahan air kepada } \\
\text { masyarakat }\end{array}$ & $\begin{array}{l}\text { Perlu dibuat fatwa } \\
\text { petinggi agama tentang } \\
\text { kelayakan air daur ulang } \\
\text { untuk keperluan ibadah }\end{array}$ \\
\hline $\begin{array}{l}\text { KEMAMPUAN } \\
\text { MASYARAKAT }\end{array}$ & $\begin{array}{l}\text { Kurangnya kemampuan } \\
\text { masyarakat akan teknologi terkini } \\
\text { untuk daur ulang air }\end{array}$ & $\begin{array}{l}\text { Belum gencarnya transfer } \\
\text { teknologi dari luar } \\
\text { Belum adanya pilot plant } \\
\text { untuk pembelajaran }\end{array}$ & $\begin{array}{l}\text { Perlu dilakukan pelatihan } \\
\text { teknologi daur ulang air } \\
\text { limbah baik di dalam } \\
\text { maupun di luar negeri }\end{array}$ \\
\hline HAKI & $\begin{array}{l}\text { Belum dapat diproduksinya } \\
\text { bahan/material yang berkualitas } \\
\text { di dalam negeri. Masih } \\
\text { mengandalkan produk luar }\end{array}$ & $\begin{array}{l}\text { Beberapa komponen } \\
\text { teknologi belum dapat } \\
\text { diproduksi di dalam } \\
\text { negeri seperti membrane } \\
\text { dan karbon aktif kualitas } \\
\text { tinggi }\end{array}$ & $\begin{array}{l}\text { Perlu transfer teknologi } \\
\text { untuk membuat material } \\
\text { yang berkualitas tinggi }\end{array}$ \\
\hline
\end{tabular}

Sumber: TNA syntesis report 2012 